\title{
PENGEMBANGAN MEDIA LAYANAN INFORMASI STUDI LANJUT BERBASIS MULTIMEDIA FLIP E-BOOK UNTUK SISWA SMA
}

\author{
Kartika Lorantina1, Lutfi Fauzan ${ }^{2}$, M. Ramli ${ }^{3}$ \\ ${ }^{1}$ Bimbingan dan Konseling niversitas Negeri Malang \\ ${ }^{2}$ Bimbingan dan Konseling niversitas Negeri Malang \\ ${ }^{3}$ Bimbingan dan Konseling niversitas Negeri Malang \\ Jl. Semarang 5 Malang 65145 \\ E-mail:lorantina.kartika@gmail.com,No Hp: 081230907869
}

\begin{abstract}
The research purposes is to result of media-based information service further studies flip multimedia e-book for high school students which acceptable theoretically and practices that can be seen in terms of usability, accuracy, attractiveness and ease. this research adopts a draft research and development from Borg \& Gall. This product development is based on the results of questionnaires and interviews with counselors and students. the result of the research are based on assessment media expert, materials expert, prospective users, and small group. of the results of the assessment it can be concluded that the flip multimedia e-book being developed fit for use and acceptable theoretical and practical.
\end{abstract}

Keywords:Information service, further studies, flip e-book, high school students

\begin{abstract}
Abstrak:Tujuan penelitian ini, yaitu menghasilkan media layanan informasi studi lanjut berbasis multimedia flip e-book untuksiswa SMA yang berterima secara teoritik dan praktik yang dapat dilihat dari segi kegunaan, ketepatan, kemenarikan dan kemudahan. Penelitian ini mengadopsi rancangan penelitian dan pengembangan Borg \& Gall. Pengembangan produk didasarkan pada hasil angket kebutuhan siswa dan wawancara dengan konselor. Hasil penelitian didasarkan pada penilaian ahli materi, ahli media, calon pengguna produk dan kelompok kecil. Dari hasil penilaian dapat disimpulkan, bahwa media multimedia flip e-book yang dikembangkan layak digunakan dan berterima secara teoritik dan praktik.
\end{abstract}

Kata kunci:Layanan informasi, Studi lanjut, Flip e-book, Siswa SMA

\section{PENDAHULUAN}

Peserta didik Sekolah Menengah Atas (SMA) adalah peserta didik yang berada pada masa remaja dengan rentang usia antara 15 sampai dengan 18 tahun. Menurut Erickson (Nurihsan, 2011) masa remaja adalah masa terjadinya krisis identitas yang mungkin bisa merupakan the best of time and the worst of time. Maksudnya jika individu mampu mengatasi berbagai tuntutan yang dihadapi secara integratif, ia akan menemukan identitasnya. Sebaliknya, jika gagal ia akan berada pada krisis identitas yang berkepanjangan. Salah satu tuntutan yang dihadapi pada masa Sekolah Menengah Atas adalah membuat keputusan studi lanjut. 
Membuat perencanaan dan keputusan studi lanjut merupakan salah satu bentuk pencarian identitas diri yang bagi sebagian peserta didik hal tersebut tidak mudah. Perlu adanya persiapan dan proses yang matang saat membuat perencanaan dan keputusan studi lanjut. Setiap individu perlu benar-benar membuat keputusan yang sesuai dengan dirinya. Karena jika tidak, kemungkinan mereka akan mengalami ketidakcocokan dan ketidaknyamanan saat menjalaninya.

Sebelum membuat keputusan studi lanjut,setiap individu perlu membuat persiapan yang matang seperti, mengenal diri, program studi dan perguruan tinggi yang ingin di tuju. Dari beberapa langkah tadi hal pertama yang dilakukan adalah mengenal diri untuk mengetahui hobi, cita-cita, hal yang disenangi dan tidak disenangi, serta kelebihan dan kekurangan diri.Setelah itu barulah peserta didik dapat membuat keputusan akan ke mana setelah SMA. Proses ini perlu disampaikan pada peserta didik karena tidak semua peserta didik memiliki informasi dan pemahaman dalam membuat perencanaan dan keputusan studi lanjut. Informasi terkait perencanaan dan keputusan studi lanjut perlu diberikan kepada pesert didik agar mereka dapat memilih studi lanjut sesuai dengan dirinya. Dalam hal ini guru Bimbingan dan Konseling memiliki peran penting dalam memberikan bimbingan kepada peserta didik dalam membuat perencanaan studi lanjut salah satunya menggunakan media Bimbingan dan Konseling.

Secara etimologis media merupakan perantara atau pengantar suatu pesan dari si pengirim (sender) kepada si peenrima (reciever) pesan (Bovee, dalam Asyhar 2012). Sedangkan secara terminologis menurut Gagne (dalam Asyar, 2012) media merupakan berbagai komponen pada lingkungan belajar yang membantu pembelajar dalam belajar. The Association for educational Communication and Technology (dalam Asyhar, 2012:4) menyatakan bahwa media adalah apa saja yang digunakan untuk menyalurkan informasi. Dari beberapa pengertian di atas dapat disimpulkan bahwa media memiliki peran yang penting, yaitu suatus sarana yang berfungsi sebagai perantara untuk menyampaikan pesan.

Media memiliki peran yang sangat penting dalam menyampaikan informasi pada penerima pesan. Ada banyak ragam pilihan media yang 
dapat digunakan guru Bimbingan dan Konseling untuk menyampaikan layanan bimbingan dan konseling pada peserta didik. Meski demikian tidak semua guru Bimbingan dan Konseling mampu memilih dan menggunakan media khususnya yang menarik bagi peserta didik. Hal tersebut terlihat dari hasil observasi yang telah di lakukan peneliti di SMAN 1 Ngimbang. Peneliti telah melakukan observasi dan wawancara dengan guru Bimbingan dan Konseling di SMAN 1 Ngimbang, hasilnya adalah guru Bimbingan dan Konseling telah menggunakan beragam media, seperti modul, brosur, powerpoint, video sebagainya. Menurut pengamatan, media yang digunakan masih terbilang konvensional. Artinya media yang digunakan kurang menarik dan kurang memandirikan peserta didik.

Hasil temuan lain di lapangan menunjukkan bahwa sebanyak $80 \%$ peserta didik belum memiliki pandangan dan rencana akan ke mana setelah SMA. Berdasarkan hasil wawancara dan observasi menunjukkan bahwa peserta didik cenderung pasif dalam mencari informasi terkait studi lanjut. Hanya beberapa peserta didik yang memiliki antusias untuk mencari informasi dan memikirkan perencanaan studi lanjutnya. Beberapa alasan yang membuat peserta didik kurang tertarik mencari informasi adalah kurangnya pemberian informasi dan kurang menariknya media yang digunakan.

Media yang digunakan guru Bimbingan dan Konseling di sekolah tersebut memang cukup variatif yang terkadang menggunakan media berupa video namun hal tersebut masih belum mampu meningkatkan antusias peserta didik. Beberapa faktor yang mempengaruhi, yaitu penggunaan media informasi yang lebih banyak menggunakan media cetak seperti brosur, booklet, dan papan bimbingan.

Penggunaan media cetak seperti modul, brosur merupakan media yang sering digunakan karena mudah untuk dikembangkan maupun dicari berbagai sumber. Namun, kebanyakan media cetak sangat tergantung pada verbal symbol (kata-kata) yang bersifat abstrak dan menuntut kemampuan abstraksi yang sangat tinggi. Menurut Asyar (2012)hal tersebut dapat menyulitkan siswa. Oleh karena itu, perlu dikembangkan sebuah media yang menarik dan dapat merangsang semua indera siswa. Salah satu media yang dapat digunakan yaitu multimedia flip e-book. Sebuah buku digital 3D yang dapat disisipi musik, gambar, dan video sehingga dapat 
menarik minat siswa, merangsang semua inderanya dan juga memandirikan.

\section{METODE}

Penelitian dan pengembangan ini menggunakan model rancangan penelitian dan pengembangan dari Borg \& Gall. Ada sepuluh langkah pelaksanaan strategi penelitian dan pengembangan, namun karena keterbatasan waktu maka peneliti hanya menggunakan lima langkah strategi penelitian dan pengembangan. Adapun langkah yang dilaksanakan, yaitu 1) penelitian dan pengumpulan data; 2) perencanaan; pengembangan draft produk; 4) uji coba produk; dan 5) merevisi hasil uji coba. Dengan demikian, penelitian pengembangan ini berbatas pada uji kelompok kecil.

Langkah pertama, penelitian dan pengumpulan data, pada tahap ini peneliti melakukan pengumpulan data melalui need assesment berupa angket dan wawancara terbuka dengan guru Bimbingan dan Konseling dan peserta didik. Selanjutnya hasil tersebut diidentifikasi, dianalisis dan di tetapkan berdasarkan prioritas kebutuhan.

$\begin{array}{crc}\text { Langkah } & \text { kedua } & \text { yaitu } \\ \text { perencanaan, } & \text { kegiatan } & \text { yang }\end{array}$

dilaksanakan ialah menentukan tujuan, subyek pengguna dan deskripsi komponen produk. Pada penelitian ini tujuan pengembangan, yaitu menghasilkan media layanan informasi studi lanjut berbasis multimedia flip $e^{-}$ book yang berterima secara teoretik dan praktik yang dapat dilihat dari segi kegunaan, ketepatan, kemenarikan, dan kemudahan. Sedangkan subyek pengguna, yaitu guru Bimbingan dan Konseling dan peserta didik kelas XI SMAN 1 Ngimbang.

Langkah ketiga yaitu pengembangan draft produk, kegiatan yang dilakukan yaitu menyusun media dan melaksanakan evaluasi atau uji di atas meja yang dilakukan oleh ahli materi dan media. Evaluasi atau uji diatas meja dilaksanakan dengan cara mengisi angket penilaian dan lembar saran.

Langkah keempat yaitu uji coba lapangan, setelah dilakukan uji di atas meja dan telah di revisi selanjutnya peneliti melakukan uji coba lapangan di SMAN 1 Ngimbang. Uji coba perlu di lakukan di lapangan karena menurut Sukmadinata, 2016) hal tersebut untuk mengetahui keberterimaan produk seseuai dengan kondisi nyata di lapangan. Selanjutnya subyek uji coba lapangan ini, yaitu 
guru Bimbingan dan Konseling dan peserta didik kelas XI IIS sebanyak 6 orang yang telah dipilih secara acak oleh peneliti .

Langkah kelima, yaitu penyempurnaan akhir produk. Pada tahap ini peneliti melakukan perbaikan produk sesuai dengan hasil uji di atas meja dan uji lapangan yang telah di lakukan. Hal tersebut perlu dilakukan agar produk yang dikembangkan memiliki keberterimaan yang sesuai dengan teoretik dan praktik serta layak di implementasikan di sekolah, khususnya di tingkat SMA.

Produk akhir dari penelitian dan pengembangan ini, yaitu Multimedia flip e-bookyang merupakan sebuah buku digital dalam bentuk 3D yang dapat dibuka seperti buku sungguhan dengan cara meng-klik ujung buku. Kelebihan dari flip e-book ini, yaitudapat disisipkan video, musik dan gambar yang dapat mengurangi kejenuhan siswa dan merangsang inderanya.

$$
\text { Multimedia flip e-book }
$$
dikembangkan menggunakan software Kvisoft flip book maker pro. Caranya cukup mudah, peneliti cukup mengkonversi file dalam bentuk pdf dan memasukkannya pada software tersebut. Namun keterbatasan dari media ini, yaitu hanya dapat dibuka melalui perangkat komputer atau Laptop yang sudah terinstall adobe flash player.

Selanjutnya data yang diperoleh pada penelitian dan pengembangan ini, yaitu berupa data kuantitatif dan kualitatif. Data kuantitatif diperoleh dari skala penilaian yang diberikan pada ahli media, ahli materi, dan calon pengguna.Sedangkan data kualitatif diperoleh dari saran balikan yang diberikan oleh ahli materi, ahli media calon pengguna produk, dan kelompok kecil. Data yang terkumpul dianalisis menggunakan teknik analisis data statistik deskriptif, yaitu teknik analisis yang memaparkan data secara nyata berdasarkan hasil yang diperoleh.

\section{PEMBAHASAN}

Produk akhir dari penelitian dan pengembangan ini, yaitu media layanan informasi studi lanjut berbasis multimedia flip e-book untuk siswa SMA. Produk ini dikembangkan melalui lima tahapan penelitian dan pengembangan dan memiliki keberterimaan secara teoretik dan praktik.

Media layanan informasi studi lanjut berbasis multimedia flip e-book 
dikemas dalam bentuk DVD yang dapat dengan mudah dibuka pada perangkat komputer atau laptop pengguna tanpa memerlukan instalasi yang rumit. Flip e-bookini berisi informasi tentang mengenal diri dan mengenal perguruan tinggi. Selain materi yang dipaparkan dalam bentuk tulisan, flip e-book ini juga dilengkapi dengan gambar, musik dan video yang dapat menarik minat siswa dalam mencari informasi.Pada flip ebook tersebut juga dilengkapi panduan penggunaan untuk peserta didik sehingga peserta didik dapat menggunakan media tersbeut secara mandiri.

Selain menghasilkan produk berupa flip ebook untuk peserta didik, penelitian dan pengembangan ini juga menghasilkan buku panduan untuk guru Bimbingan dan Konseling. Buku panduan ini berupa buku cetak menggunakan kertas berukuran A5 . Isi dari buku panduan untuk guru Bimbingan dan Konseling, yaitu petunjuk kegiatan, petunjuk penggunaan, dan materi.

Isi dari media layanan informasi berbasis multimedia flip ebook yaitu informasi mengenai diri dan informasi mengenai perguruan tinggi. Hal tersebut merujuk pada pendapat Widada (1990:47) yang menyatakan bahwa, "secara garis besar layanan informasi terdiri dari dua hal, yaitu informasi tentang diri siswa, dan informasi tentang lingkungan diluar diri siswa".

Berikut ini adalah isi dari produk yang dikembangkan, 1) informasi tentang cara mengenal diri berisi informasi mengenal bakat, minat, cita-cita, dan hobi yang di akhir pembahasan disisipi dengan video potensi diri; dan 2) informasi tentang melanjutkan kuliah, seperti bentuk dan status perguruan tinggi, syarat dan jalur masuk perguruan tinggi, program pendidikan dan program studi, biaya, beasiswa, dan hal yang perlu dipertimbangkan dalam memilih studi lanjut. Pada bagian akhir, peneliti menyisipkan video profil beberapa perguruan tinggi. Pemilihan profil perguruan tinggi ini berdasarkan hasil angket yang diberikan pada peserta didik.

Riyana (dalam Asyar, 2012:29), menyatakan melalui media suatu proses pembelajaran bisa lebih menarik dan menyenangkan (joyfull learning). Dengan menggunakan media berteknologi seperti halnya komputer, multimedia, internet, dan lain-lain sangat membantu peserta didik dalam belajar memperkaya pengetahuan. Berdasarkan hal tersebut maka pada 
flip e-book ini diberikan menu galeri yang berisi profil beberapa perguruan tinggi di Indonesia.

Tujuan dari diberikannya video profil perguruan tinggi dan potensi diri, yaitu agar siswa dapat memperkaya pengetahuannya dan tidak belajar secara abstrak. Media ini diharapkan dapat meningkatkan pemahaman siswa tentang informasi yang diberikan.

Untuk mengukur ketercapaian pemahaman siswa berkaitan dengan informasi yang diberikan, maka pada flip e-book ini diberikan evaluasi untuk siswa. Evaluasi yang diberikan yaitu pertanyaan mengenai materi yang telah dipelajari sebelumnya, dan siswa diminta untuk menuliskan rencana studinya.

\begin{tabular}{lll}
\hline No & Topik & \multicolumn{1}{c}{ Sub Topik } \\
\hline 1 & Who am I? & Mengenal bakat \\
\hline & & Mengenal cita-cita \\
\hline & & Mengenal hobi \\
\hline 2 & Jika Aku & Bentuk dan status \\
& Kuliah & perguruan tinggi \\
\hline & & Syarat dan jalur \\
& & masuk perguruan \\
& & tinggi \\
\hline & & Program \\
& & Pendidikan dan \\
& & Program studi \\
\hline & & Biaya dan beasiswa \\
\hline & & Menentukan \\
& & pilihan \\
\hline 3 & Profil & Video profil \\
& Perguruan & universitas negeri \\
& Tinggi & malang \\
\hline & & Video profil \\
& & universitas \\
\hline & &
\end{tabular}

\begin{tabular}{ll}
\hline airlangga \\
\hline Video profil \\
universitas gajah \\
mada \\
\hline Video profil \\
universitas \\
indonesia \\
\hline Video profil \\
universitas \\
diponegoro \\
\hline Video profil \\
institute teknologi \\
sepuluh nopember \\
\hline Video profil \\
institute teknologi \\
bandung \\
\hline Video profil \\
Sekolah Tinggi \\
Akuntansi \\
\hline Video profil sekolah \\
tinggi transportasi \\
darat \\
\hline Video profil sekolah \\
tinggi ilmu \\
statistik \\
Video profil ilmu \\
pemerintahan \\
dalam negeri
\end{tabular}

Selain flip e-book untuk siswa produk yang dihasilkan, yaitu buku panduan untuk konselor yang berisi, 1) pendahuluan, 2) tujuan dari penggunaan flip e-book sebagai media layanan informasi studi lanjut, 3) karakteristik media flip e-book, 4) kegiatan konselor, 5) fitur dan petunjuk penggunaan flip e-book, dan 6) materi 7) soal evaluasi dan jawaban. buku panduan konselor dibuat untuk mempermudah konselor dalam menyampaikan informasi.

Kelayakan dan keberterimaan produk dinilai oleh ahli media dan ahli materi melalui evaluasi atau uji di atas 
meja. Evaluasi atau uji di atas meja perlu dilakukan sebelum produk yang dibuat di uji lapangan pada calon pengguna dan kelompok kecil.

Subyek ahli materi, yaitu Widada, M.Si seorang dosen Bimbingan dan Konseling Universitas Negeri Malang, dengan bidang keahlian layanan BK. Sedangkan ahli media yaitu Henry Praherdiono, S.Si, M.Pd seorang dosen Teknologi Pendidikan Universitas Negeri Malang dengan bidang keahlian media pembelajaran. Kelayakan produk dinilai dari segi kegunaan, ketepatan, kemenarikan dan kemudahan. Hasil penilaian ahli media dan materi, yaitu flip e-book yang dibuat layak dan perlu revisi. Berikut adalah hasil penilaian yang dilakukan oleh ahli media dan ahli materi

Tabel Penilaian Ahli Materi

\begin{tabular}{lccl}
\hline ASPEK & $\begin{array}{r}\text { Skor } \\
\text { total }\end{array}$ & $\begin{array}{c}\text { Skor } \\
\text { rata- } \\
\text { rata }\end{array}$ & Validasi \\
\hline Kemenarikan & 22 & 3.14 & $\begin{array}{l}\text { Sangat } \\
\text { menarik }\end{array}$ \\
Kemudahan & 12 & 3 & Mudah \\
Ketepatan & 18 & 3 & Tepat \\
Kegunaan & 20 & 4 & $\begin{array}{l}\text { Sangat } \\
\text { berguna }\end{array}$ \\
\hline
\end{tabular}

\begin{tabular}{llll}
\multicolumn{3}{c}{ Tabel Penilaian Ahli Media } \\
\hline ASPEK & $\begin{array}{l}\text { Skor } \\
\text { total }\end{array}$ & $\begin{array}{c}\text { Skor } \\
\text { rata- } \\
\text { rata }\end{array}$ & Validasi \\
& &
\end{tabular}

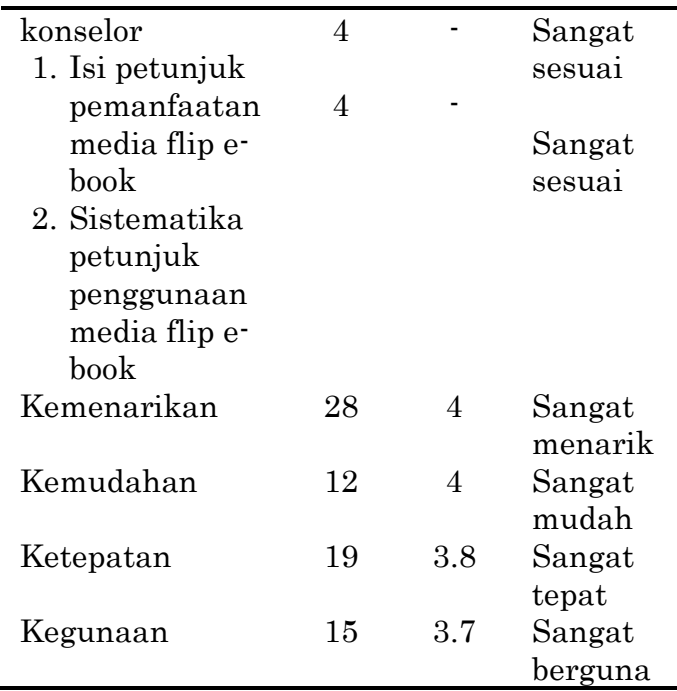

Ahli uji calon pengguna produk adalah Tutik Setyoningsih, S.Pd selaku guru Bimbingan dan Konseling kelas XI SMAN 1 Ngimbang. Berikut adalah hasil penilaian yang di berikan.

Secara ringkas dapat dijabarkan dalam tabel berikut ini

Tabel Hasil Keberterimaan Produk

\begin{tabular}{|c|c|c|c|c|}
\hline \multirow[t]{2}{*}{ No } & \multirow[t]{2}{*}{ aspek } & \multicolumn{2}{|c|}{ Penilaian ahli } & \multirow{2}{*}{$\begin{array}{c}\text { Calon } \\
\text { penggu } \\
\text { na }\end{array}$} \\
\hline & & Materi & media & \\
\hline 1 & $\begin{array}{l}\text { Kemen } \\
\text { arikan }\end{array}$ & $\begin{array}{l}\text { Sangat } \\
\text { menari } \\
\mathrm{k}\end{array}$ & $\begin{array}{l}\text { Sangat } \\
\text { menari } \\
\mathrm{k}\end{array}$ & $\begin{array}{l}\text { Menari } \\
\mathrm{k}\end{array}$ \\
\hline 2 & $\begin{array}{l}\text { Kemud } \\
\text { ahan }\end{array}$ & Mudah & $\begin{array}{l}\text { Sangat } \\
\text { mudah }\end{array}$ & $\begin{array}{l}\text { Sangat } \\
\text { mudah }\end{array}$ \\
\hline 3 & $\begin{array}{l}\text { Ketepa } \\
\text { tan }\end{array}$ & Tepat & $\begin{array}{l}\text { Sangat } \\
\text { tepat }\end{array}$ & $\begin{array}{l}\text { Sangat } \\
\text { tepat }\end{array}$ \\
\hline 4 & $\begin{array}{l}\text { Kegun } \\
\text { aan }\end{array}$ & $\begin{array}{l}\text { Sangat } \\
\text { bergun } \\
\text { a }\end{array}$ & $\begin{array}{l}\text { Sangat } \\
\text { bergun } \\
\text { a }\end{array}$ & $\begin{array}{l}\text { Sangat } \\
\text { bergun } \\
\text { a }\end{array}$ \\
\hline
\end{tabular}


Langkah yang dilaksanakan setelah melalui "uji diatas meja" oleh ahli materi dan ahli media, yaitu uji calon pengguna dan kelompok kecil. Penilaian dilaksanakan dengan cara memberikan skor pada angket penilaian dan memberikan saran. Hasil penilaian calon pengguna, yaitu flip e-book yang dibuat sudah bagus dan layak digunakan. Sedangkan saran yang diperoleh dari penilaian kelompok kecil, yaitu sebaiknya menggunakan profil perguruan tinggi terbaru. Menanggapi saran yang diberikan oleh kelompok kecil, peneliti berusaha menyajikan profil perguruan tinggi terbaru, namun karena keterbatasan sumber dan waktu ada beberapa profil yang tidak terbaru. Namun meski demikian, informasi yang disajikan dapat menambah pemahaman siswa.berikut hasil penilaian oleh calon pengguna

Tabel Penilaian Calon Pengguna

\begin{tabular}{|c|c|c|c|}
\hline ASPEK & $\begin{array}{l}\text { Skor } \\
\text { total }\end{array}$ & $\begin{array}{c}\text { Skor } \\
\text { rata- } \\
\text { rata }\end{array}$ & validasi \\
\hline Kemenarikan & 12 & 3 & Menarik \\
\hline Kemudahan & 15 & 3.75 & $\begin{array}{l}\text { Sangat } \\
\text { Mudah }\end{array}$ \\
\hline Ketepatan & 19 & 3.16 & $\begin{array}{l}\text { Sangat } \\
\text { Tepat }\end{array}$ \\
\hline Kegunaan & 16 & 3.2 & $\begin{array}{l}\text { Sangat } \\
\text { berguna }\end{array}$ \\
\hline
\end{tabular}

Uji kelompok kecil dilakukan peneliti dengan memberikan bimbingan layanan informasi kepada siswa dalam kelompok kecil dengan subyek 6 orang siswa kelas XI IIS 2 . Uji kelompok kecil dilaksanakan untuk menilai keberterimaan produk secara mikro (Sukmadinata, 2013). Teknik yang digunakan yaitu, ekspositori, diskusi kelompok dan latihan. Teknik ini diadopsi dari teknik bimbingan kelompok yang dikemukakan oleh Tatiek Romlah. Pemilihan teknik ini dinilai sesuai karena membuat siswa menjadi aktif dalam membaca informasi dan mengemukakan pendapat.

\section{PEMBAHASAN}

Berdasarkan hasil penilaian ahli, materi yang disajikan pada flip ebook sudah tepat dan sangat menarik. Ketepatan dan kemenarikan materi yang disajikan didukung oleh pendapat Widada (1990:47) yang menyatakan bahwa, secara garis besar layanan informasi terdiri dari dua hal, yaitu informasi tentang diri siswa, dan informasi tentang lingkungan diluar diri siswa. Merujuk pada pendapat Widada (1990:47), maka materi flip $e^{-}$ book yang dikembangkan, berisi 1) informasi tentang cara mengenal diri seperti bakat, minat, cita-cita, hobi, disertai dengan video potensi diri 2) informasi tentang melanjutkan kuliah, 
seperti bentuk dan status perguruan tinggi, syarat dan jalur masuk perguruan tinggi, program pendidikan dan program studi, biaya, beasiswa, dan hal yang perlu dipertimbangkan dalam memilih studi lanjut.

$$
\text { Penilaian ahli media }
$$

menunjukkan bahwa media yang dikembangkan sangat menarik, sangat mudah, sangat tepat, dan sangat berguna. Riyana (dalam Asyar, 2012:29) menyatakan bahwa penggunaan media yang menarik menjadikan proses pembelajaran lebih menarik dan menyenangkan (joyfull learning). Merujuk pernyataan tersebut, maka peneliti tidak hanya menyisipkan gambar namun juga menyisipkan musik dan video sehingga siswa tidak bosan. Melalui media yang menarik menjadikan siswa lebih antusias mengikuti layanan yang diberikan oleh konselor.

Penilaian produk oleh calon pengguna juga menunjukkan hal sama,yaitu media yang dikembangkan menarik, sangat mudah, sangat tepat, dan sangat berguna. Konselor sebagai calon pengguna menyatakan jika media yang digunakan sangat mudah dioperasikan sekalipun oleh orang yang kurang bisa mengoperasikan komputer. Materi yang diberikan juga sangat membantu siswa dalam memahami perencanaan studi lanjutnya. Dengan disisipkannya beberapa video profil perguruan tinggi membantu siswa dalam mengenal perguruan tinggi yang diinginkan, macam perguruan tinggi dan gambaran perkuliahan.

Setelah melalui tahap penilaian ahli dan calon pengguna, maka selanjutnya dilakukan uji kelompok pada siswa kelas XI IIS 2 sejumlah 6 orang siswa yang dipilih secara random. Uji kelompok kecil dilaksanakan untuk menilai keberterimaan produk secara mikro (Sukmadinata, 2013). Teknik yang digunakan dalam penyampaian materi, yaitu ekspositori, diskusi kelompok dan latihan. Teknik yang dipilih sesuai karena dapat membuat siswa menjadi lebih aktif mengikuti layanan dan mengemukakan pendapat. Uji kelompok kecil menunjukkan bahwa media yang digunakan menarik, mudah digunakan dan meningkatkan pemahaman siswa dalam merencanakan studi lanjutnya.

Hasil yang diperoleh dari uji kelompok kecil sebanding dengan hasil penelitian yang telah dilakukan oleh Kurniawan (2013), dan Sugianto, dkk (Invotec, vol. IX;2;115) bahwa modul virtual multimedia flip e-book sangat mudah dioperasikan, materi yang 
dipelajari mudah dipahami oleh siswa.

Selain itu unsur musik dan animasi dinilai dapat meningkatkan motivasi, minat, dan aktivitas belajar siswa.

Dari uraian diatas dapat disimpulkan bahwa media flip $e^{-}$ bookmerupakan alat bantu konselor dalam menyampaikan informasi studi lanjut yang memandirikan bagi siswa. Yang dimaksud memandirikan, yaitu siswa dapat membaca dan mempelajari isi informasi dengan atau tanpa didampingi konselor. Namun demikian, konselor tetap bertugas mendampingi dan mengevaluasi pemahaman siswa. Hal tersebut sesuai dengan pendapat Widada (1990) yang mengemukakan, ada tiga kemungkinan peranan konselor dalam menyampaikan informasi studi lanjut, salah satunya menggunakan media tetapi konselor tetap aktif hadir sebagai pendamping siswa dalam belajar.

Kelebihan multimedia flip e-book ini, yaitu 1) konselor dapat menggunakan flip e-book ini sebagai media yang menarik karena dapat disisipi gambar, video, dan musik, 2) flip e-book dapat menarik perhatian siswa dan dapat mengurangi kejenuhan siswa dengan adanya fiturfitur yang ditambahkan seperti musik, gambar, video, dan siswa dapat membagikannya melalui email dan media sosial, 3) flip e-book mudah digunakan tanpa memerlukan installasi yang rumit pada PC, 4) dapat dijadikan sebagai media layanan informasi yang memandirikan bagi siswa, baik dirumah maupun di sekolah tanpa didampingi konselor, 5) dapat dibuka secara offline atau tanpa jaringan internet, kecuali jika ingin membagikannya melalui media sosial dan email.

Sedangkan kelemahannya, yaitu 1) flip e-book hanya dapat dibuka pada PC yang sudah terinstall adobe flash player, 2) informasi yang disampaikan cenderung kurang mendapat perhatian dari pembaca, karena pembaca cenderung lebih tertarik dengan video yang diberikan.

Menurut Riyana (dalam Asyar, 2012:29), melalui media suatu proses pembelajaran bisa lebih menarik dan menyenangkan (joyfull learning). Dari hasil penelitian ini terlihat bahwa multimedia flip e-book yang digunakan untuk menyampaikan informasi studi lanjut mampu menarik perhatian dan minat siswa dalam membaca dan mencari informasi studi lanjut. Melalui media ini pemahaman siswa juga meningkat. Berdasarkan uraian dari pendapat ahli dan penelitian terdahulu, dapat disimpulkan bahwa media layanan informasi studi lanjut 
berbasis multimedia flip e-book untuk siswa SMA ini, layak digunakan di sekolah yang berterima secara teoritik dan praktik. Selain itu, media yang dibuat merupakan media yang menarik dan memandirikan bagi siswa.

Dari hasil penelitian ini terlihat bahwa multimedia flip e-book yang digunakan untuk menyampaikan informasi studi lanjut mampu menarik perhatian dan minat siswa dalam membaca dan mencari informasi studi lanjut. Melalui media ini pemahaman siswa juga meningkat. Berdasarkan uraian dari pendapat ahli dan penelitian terdahulu, dapat disimpulkan bahwa media layanan informasi studi lanjut berbasis multimedia flip e-book untuk siswa SMA ini, layak digunakan di sekolah yang berterima secara teoritik dan praktik. Selain itu, media yang dibuat merupakan media yang menarik dan memandirikan bagi siswa.

\section{SIMPULAN}

Hasil penelitian dan
pengembangan ini, yaitu media
informasi studi lanjut berbasis
multimedia flip e-book untuk siswa
SMA dan sebuah buku panduan untuk
konselor. Dari hasil penelitian ini
terlihat bahwa multimedia flip e-book

yang digunakan untuk menyampaikan informasi studi lanjut mampu menarik perhatian dan minat siswa dalam membaca dan mencari informasi studi lanjut. Melalui media ini pemahaman siswa juga meningkat. Hal ini terlihat dari hasil evaluasi yang diberikan kepada siswa. Teknik yang digunakan yaitu, ekspositori, diskusi kelompok dan latihan. Teknik ini diadopsi dari teknik bimbingan kelompok yang dikemukakan oleh Tatiek. Pemilihan teknik ini dinilai sesuai karena membuat siswa menjadi aktif dalam membaca informasi dan mengemukakan pendapat.

Berdasarkan uraian dari pendapat ahli dan penelitian terdahulu, dapat disimpulkan bahwa media layanan informasi studi lanjut berbasis multimedia flip e-book untuk siswa SMA ini, layak digunakan di sekolah yang berterima secara teoretik dan praktik. Flip e-book dapat digunakan sebagai alat bantu konselor dalam menyampaikan informasi studi lanjut pada siswa. maksudnya, konselor tetap aktif mendampingi dan membimbing siswa. Selain itu, media yang dibuat merupakan media yang menarik dan memandirikan bagi siswa.Mereka lebih antusias dalam mencari informasi, terutama dengan melihat video yang diberikan. 


\section{SARAN}

Flip e-book ini diharapkan dapat digunakan konselor sebagai salah satu media layanan informasi studi lanjut untuk siswa kelas XI khususnya siswa SMAN 1 Ngimbang, Lamongan. Flip ebook ini diharapkan dapat menjadi media yang menarik dan memandirikan bagi siswa, serta memudahkan konselor dalam penyampaian layanan informasi studi lanjut. Apabila media ini digunakan di sekolah lain, sebaiknya dilakukan penyesuaian dengan kebutuhan siswa dan keadaan di sekolah tersebut agar layanan yang diberikan dapat efektif.

$$
\text { Bagi peneliti selanjutnya, }
$$
hendaknya dilakukan penelitian lebih lanjut untuk mengetahui keefektifan flip e-book sebagai media layanan informasi studi lanjut untuk siswa SMA. Bagi konselor hendaknya dilakukan evaluasi untuk mengetahui kelebihan dan kelemahan dari produk yang dihasilkan jika diterapkan pada siswa dalam kelompok besar. Konselor diharapkan juga lebih kreatif untuk mengembangkan media yang sama. Sedangkan bagi peneliti yang ingin mengembangkan media yang sama, hendaknya dapat mengemas informasi lebih menarik dan berimbang dengan video yang disisipkan. Sehingga perhatian siswa tidak hanya pada video.

\section{DAFTAR RUJUKAN}

Asyar,

R. 2012 .

Kreatif

Mengembangkan Media

Pembelajaran.

Referensi:Jakarta

Kurniawan, Ch.2013. Pengembangan

Media Pembelajaran Flip

Ebook Dalam Kompetensi

Dasar Mengidentifikasi

Sistem Starter Pada

Kendaraan Untuk Siswa

Kelas X Kompetensi Keahlian

Teknik Ototronik Di SMK

Negeri 1 Singosari. Skripsi

Universitas Negeri

Malang:Malang

Kumala, Y. 2013.E-book "Transformasi

Buku di Era Digital",(online),

(http://kumala-

thekumalas.blogspot.com/201

3/01/e-book-transformasi-

buku-di-era-digital.html),

diakses 19 November 2014)

Nurihsan, A.J. 2011. Bimbingan \& Konseling Dalam Berbagai

Latar Kehidupan. Refika

Aditama:Bandung

Peraturan Pemerintah Republik Indonesia Nomor 14 Tahun 2010 Tentang Pendidikan Kedinasan, (online), (, diakses 23 Februari 2015 
Sidharta,K. 2013. Membaca eBook

Layaknya Membaca Buku

dengan Flipping PDF Reader,

(online),

(http://www.pusatgratis.com/sof

tware/membaca-ebook-

layaknya-membaca-buku-

dengan-flipping-pdf-

reader.html), diakses 19

November 2014

Sugianto, Doni, dkk. 2013. Modul

Virtual: Multimedia Flipbook

Dasar Teknik Digital.Invotec,

(online), IX (2):101-116

(http://jurnal.upi.edu/file/01._D

oni_Sugianto_101-116_.pdf),

diakses 24 Maret 2015

Sukardi, K.1983. Dasar-dasar

Bimbingan dan Penyuluhan di

Sekolah. Usaha

Nasional:Surabaya

Sukmadinata, N.S. 2013. Metode penelitian pendidikan. remaja rosdakarya:Bandung

Undang Republik Indonesia Nomor 22 Tahun 1961 tentang Perguruan Tinggi. (online), (http://hukum.unsrat.ac.id/uu/u u_22_1961.htm), diakses 23

Pebruari 2015

Winkel, W.S. 1987. Bimbingan dan Konseling di Sekolah

Menengah. Gramedia:Jakarta 